\title{
Assessment of Consumer Awareness on Environmental Effects of Charcoal Production and Use in Nairobi City, Kenya
}

\author{
Walter Angwere Onekon ${ }^{1}$, Koech Oscar Kipchirchir ${ }^{2}$ \\ ${ }^{1}$ Africa Nazarene University, Department of Environment \& Natural Resource Management, \\ Nairobi, P.O Box 53067-00200, Nairobi, Kenya \\ ${ }^{2}$ University of Nairobi, Department of Land Resource Management and Agricultural Technology, \\ Kenya. P.O Box 209053-00625, Nairobi, Kenya
}

\begin{abstract}
This study investigated the awareness of the urban population on the effects of charcoal production and use on the environment. Specifically, the study evaluated the charcoal production techniques in Kenya, identified the different types of cooking stoves used and cooking environments adopted by charcoal users as well as investigated the level of awareness of the population of Nairobi on the effects of charcoal production and use on environmental degradation. Survey research design was used in this study involving the use of semi-structured questionnaire, with a target of 100 respondents (20 large scale charcoal traders and 80 charcoal users) sampled through person-to-person interview, selected using purposive/systematic random sampling technique. Descriptive and inferential statistical data techniques were used to analyze the field data in Microsoft Excel and SPSS (Version 20). The findings of this study revealed traditional charcoal production techniques to be high (100\%) among producers supplying Nairobi city. Significant low level $(<50 \%)$ awareness by charcoal users and traders on the negative effects of charcoal production to the environment was also noted. Most users (93\%) do not use energy conserving stoves for their cooking and heating activities. This is a big challenge to the highly predicted forest cover depletion, which is affecting the rooting of a green economy in Kenya. The findings reveal charcoal production as the main energy source, coupled with low awareness on environmental impacts by the producers and users. Biodiversity loss and reduced water cycling was poorly pointed as other environmental effects from deforestation from charcoal. This calls for urgent need on public awareness on energy saving technologies on charcoal production and use, government legislations on charcoal production with focus on reforestation and afforestation to be reinforced nation-wide if Kenya hopes to transition to a sustainable green economy within its vision 2030 agenda. Mechanisms to allow access to green energy sources by the government are also urgently needed to reduce reliance on charcoal. The findings suggest the need for mitigation measures in order to minimize environmental impacts at local, national and global levels from charcoal production and use. The environment and particularly the forest is a major aspect in the drive towards sustainable development and therefore adopting a policy framework that protects the forest from uncontrolled charcoal production and use is imperative.
\end{abstract}

Keywords: Charcoal production; Charcoal use; Green economy; Environmental degradation; Forest cover depletion; Nairobi city

\section{Introduction}

The awareness of the charcoal producers and users of the effects of charcoal use on the environment particularly forest cover depletion and their health is likely to reduce charcoal production and use, and therefore safe the forest and conserve the environment as a whole. Awareness will not only save the forest but will also enhance environmental services like water purification, carbon dioxide $\left(\mathrm{CO}_{2}\right)$ sequestration, clean air [reduced emissions of Greenhouse Gases (GHGs)] like carbon dioxide and methane, nutrients cycling and provision of food, fodder and other materials necessary for human wellbeing. Population awareness on environmental effects of charcoal production can contribute positively to adoption of cheaper and cleaner energy sources like Liquefied Petroleum Gas (LPG) and Electricity (Kituyi, 2004; Mohammed et al, 2013). These energy sources are low in $\mathrm{CO}_{2}$ emissions - a critical characteristic of a green economy. Since awareness on the negative effects of charcoal production and use on the environment as a whole is low, users of charcoal will continue to use charcoal for cooking and heating and this means continuous production of the same. This is particularly so as charcoal production trends have been reported to be ever increasing. The trends show steady increase in production tonnage from 869,016;
902,$486 ; 937,245$; 971,086 ; to $1,006,148$ in the year 2008 , 2009, 2010, 2011 and 2012 respectively (FAOSTAT, 2016). This will lead to the felling down of trees by charcoal producers to meet the demand of the users. The ultimate consequence is that the forest is depleted. Other studies have reported low knowledge by urban population on the effects of charcoal and fuel wood use as a major threat to ecosystem well being (Njenga et al. 2013; Bekele \& Girmay, 2014; Jagger, 2014).

Pawar and Rothkar (2015) hold that awareness on the environmental and health effect particularly by the users of charcoal is very low. Although charcoal production can be considered a lucrative activity and its main product (charcoal) being an energy source reachable by about $70 \%$ of Kenya's population, there is urgent need for awareness creation (Njenga et al, 2013) on the effect of this activity on present and future forest cover availability (Mwampamba, 2007). In fact there are a plethora of dangers emanating from forest cover depletion. Reason why people and governments should be educated on the dangers of overexploiting forest resources, especially wood (Pawar \& Rothkar, 2015). Pawar \& Rothkar (2015) insist that the effects of forest cover depletion are long lasting and devastating and therefore the participation of all mankind in forest conservation is not 


\section{International Journal of Science and Research (IJSR) \\ ISSN (Online): 2319-7064}

Index Copernicus Value (2013): 6.14 | Impact Factor (2015): 6.391

only vital, but dire. This can only be achieved when people take informed decisions like limiting their demand on charcoal and adopting the use of energy sources like LPG, thereby by saving the forest and reducing emissions of GHGs.

Tesot (2012) establishes that the use of charcoal started about 30,000 years ago. Charcoal which is mankind's first source of energy refers to a range of carbonized materials constituting different levels of combustion and dark properties (Lurimuah, 2011; Tesot, 2012). Although charcoal is a major source of income for some rural and urban dwellers (Kammen \& Lew, 2005) its negative consequences cannot be undermined. Burning down the forest to satisfy energy needs for household cooking and heating creates direct environmental and health issues (Atteridge, 2013). A likely environmental impact of charcoal production and use is the depletion of forest cover which in turn will lead to biodiversity loss, soil erosion, and changes in forest water table (Gichuho et al., 2013). Ghilardi \& Steierer (2011) hold that probable effect of charcoal production and use includes forest cover depletion, poverty, GHG emissions and health impacts. This is almost similar to the assertion of Jones (2015). He asserts that charcoal production and use in Liberia is responsible for negative externalities as a result of improper land use and resource management. These according to him come with significant health risks borne almost exclusively by the resource poor rural population. This makes the charcoal activity to have disproportionate adverse effects on the social and economic development of rural charcoal producers (Jones, 2015).

The charcoal burning footprint is $998 \mathrm{~kg} \mathrm{CO}_{2} \mathrm{e}$ and this is almost three times larger than that of Liquefied Petroleum Gas (LPG) grilling, which is $349 \mathrm{~kg} \mathrm{CO}_{2} \mathrm{e}$ (Ackah, 2015; Johnson, 2009). According to Atteridge (2013), charcoal production and use reduces the availability of mature trees as shade against increasing temperatures, which in turn increases surface runoff of precious fresh water resources. He holds that climate change will affect the growth of tree species needed for charcoal production to the effect that it will become difficult to access the desired tree species.

In Sub-Saharan Africa, charcoal carbonization process involves large portions of the wood being lost in kilns with only 10\% efficiency (Ackah, 2015; Johnson, 2009; Mugo \& Gathui, 2010). The critical effect of charcoal production as held by (Pennise et al., 2001) is carbon emissions and forest cover depletion. Pennise et al (2001) investigate that in charcoal production, $51 \%$ of the wood is converted to charcoal, $27 \%$ to $\mathrm{CO}_{2}$ and $13 \%$ as products of incomplete combustion or by-products (Ackah, 2015; Johnson, 2009). In a related study, Andreae (1991) as cited by Ackah, (2015) earlier estimates that burning biomass including the production of charcoal accounts for $2-45 \%$ of global emissions.

It can therefore, be concluded that charcoal production and use constitutes a double-edged effect on rooting a green economy in countries that do not sustainably utilize their forest resources. This is because it not only drives forest cover depletion, but also, its production process entails huge carbon emissions which increase global warming and disturb environmental services. The table below paints a picture of emissions from charcoal activity.

Table 1: Greenhouse gas emission levels caused by charcoal production in tropical ecosystems of the world, as estimated in 2009

\begin{tabular}{|c|c|c|c|c|c|}
\hline Region & \multirow{2}{*}{$\begin{array}{c}\text { Estimated } \\
\text { charcoal } \\
\text { production for } \\
2009 \text { (Million } \\
\text { tonnes) }\end{array}$} & \multicolumn{4}{|c|}{$\begin{array}{c}\text { Greenhouse gas emissions (Million } \\
\text { tonnes }\end{array}$} \\
\cline { 3 - 6 } & $\begin{array}{c}\text { Carbon } \\
\text { dioxide }\end{array}$ & Methane & $\begin{array}{c}\text { Methane } \\
\left(\mathrm{CO}_{2} \mathrm{e}\right)\end{array}$ & $\begin{array}{c}\text { Total } \\
\mathrm{CO}_{2}\end{array}$ \\
\hline Africa & 26.116 & 46.70 & 0.84 & 20.93 & 67.63 \\
\hline Asia & 5.006 & 8.95 & 0.16 & 4.01 & 12.96 \\
\hline $\begin{array}{c}\text { Central } \\
\text { America }\end{array}$ & 1.061 & 1.90 & 0.03 & 0.85 & 2.75 \\
\hline Oceania & 0.012 & 0.02 & 0.00 & 0.01 & 0.03 \\
\hline $\begin{array}{c}\text { South } \\
\text { America }\end{array}$ & 7.621 & 13.62 & 0.24 & 6.10 & 19.72 \\
\hline $\begin{array}{c}\text { Total } \\
\text { for All } \\
\text { regions }\end{array}$ & 39.816 & 71.19 & 1.27 & 31.85 & 103.04 \\
\hline
\end{tabular}

\section{Adapted from: Chidumayo \& Gumbo (2013)}

From the above discussion, this study therefore declined itself to three specific objectives including (i) to evaluate the charcoal production techniques in Kenya; (ii) to identify the different types of cooking stoves used and cooking environments adopted by charcoal users; and (iii) to investigate the level of awareness of the population of Nairobi on the effects of charcoal production and use.

\section{Materials and Methods}

\subsection{Study Area}

The study was carried out in Nairobi which is the capital city of Kenya. Nairobi is located in southern Kenya on 1000 '" N and 30000 ' $\mathrm{E}$ at an elevation of $1670 \mathrm{~m}$ above sea level. It is the most populated city in East Africa with an estimated population of $3,138,369$ (KNBS, 2013). According to Njenga (2013) the population growth rate of Nairobi is estimated at about three percent annually. As the political, administrative and business capital of Kenya, Nairobi is a centre of industry, education and culture occupying an area of $696.1 \mathrm{~km}^{2}$ and hosting about $25 \%$ of Kenya's urban population. Charcoal usage in Nairobi is widespread with $10 \%$ of the estimated 2.4 million tonnes of charcoal produced annually (Mutimba \& Baraza, 2005) consumed in the capital city, Nairobi (Njenga et al., 2013).

\subsection{Data Collection and Processing}

Semi-structured questionnaires were used as the data collection tools for this study. Prior to data collection, research assistants were imparted with training on the questions to answer the objectives of this study. Semistructured questionnaires are research tools that combine characteristics of structured and unstructured questionnaires as well as enable the researcher to gather both quantitative and qualitative data. After the training, a pre-test of the questionnaire was done to validate the tool and also ensure that all the researchers had clearly understood the issues to probe from the respondents. Yin (2003) deems 


\section{International Journal of Science and Research (IJSR) \\ ISSN (Online): 2319-7064}

Index Copernicus Value (2013): 6.14 | Impact Factor (2015): 6.391

questionnaires as one of the most important sources of information useful for understanding complex phenomena and gaining insights from the respondents for a given matter. The study also used Key Informant interviews to doublecheck the information collected through the personal interviews. This involved the lead researcher having discussions on the topic with five Kenya forestry officers. The data collected was validated to get the relevant data from the study. The validated data was coded for easy classification in order to facilitate tabulation. The tabulated data was then analyzed quantitatively by calculating various percentages where possible. To analyze statistical data, the study used Microsoft Excel and the Statistical Package for Social Science (SPSS version 20). Results obtained are presented in the form of tables, charts and graphs.

The sample population of this study was 100 respondents (20 charcoal traders and 80 charcoal users). The study obtained a sample size by using Neuman's formula for determining the sample size i.e. $\mathrm{n}=\left(\mathrm{Ncv}^{2}\right) /\left(\mathrm{cv}^{2}+(\mathrm{N}-1) \mathrm{e}^{2}\right)$ where: $\mathrm{n}=$ sample size, $\mathrm{N}=$ population is $3,138,369$ (KNBS, 2013), $\mathrm{cv}=$ coefficient of variation (used 0.5 ), e = tolerance at desired level of confidence, took 0.05 at $95 \%$ confidence level (Neuman, 2000). The formula provided a sample size of 100 respondents. A clustered random sampling was done to pick out five administrative towns (sub-counties) in Nairobi. Although the actual population of traders was not known, there was a high probability that the number of traders in a given administrative location was correlated to the population of that location (Bailis \& Kammen, 2005). The different locations were ranked by the incidence of poverty i.e. better-off locations with an incidence of poverty below $25 \%$, medium where the incidence of poverty is between $25-49 \%$ and poor where the incidence of poverty is more than 50\% (KNBS, 2013). One location (Ngara), two locations (Langata and Embakassi), and two locations (Kangemi and Kibera) were randomly selected from the better-off, medium and poor strata respectively. From these towns, a systematic random sampling was used to target charcoal traders and users (Gall et al., 2003). A systematic purposive sampling was done to select four charcoal traders per town. This was so as to pick the large scale traders stocking 100 sacks and above. This helped the researcher to get a representative cross-section of charcoal users. At each selected trader, systematic sampling was employed to select four charcoal users. The sampling interval was determined by the equation: Sampling interval $=\mathrm{t} / \mathrm{u}$. Where: $\mathrm{t}=$ proportion of traders; $u=$ proportion of users $=20 / 80=1 / 4$ i.e. 1:4 (one user after every four)

\section{Results and Discussion}

\subsection{Charcoal Production Techniques in Kenya}

The study findings on the charcoal production techniques employed by producers supplying the Nairobi city are presented in Table 2. The study sought to understand from respondents the technique of charcoal production that is widely used by the producers. Respondents were expected to choose from two options (modern and traditional kilns) presented in the questionnaires.
Table 2: Charcoal Production Techniques Identified by Respondents

\begin{tabular}{|c|c|}
\hline Type of Kiln & Percentage (\%) \\
\hline Modern kilns & 00 \\
\hline Traditional kilns & 100 \\
\hline
\end{tabular}

The finding in Table 2 is indicative of the fact that higher proportion of the charcoal production in Kenya is done using traditional techniques. This finding agrees with that of Njenga et al. (2013) who found that almost all of the charcoal in Kenya was produced using traditional kilns which are very inefficient. This explains why about 135,000 hectares of forest are depleted each year to provide for charcoal demands in Kenya (KFS, 2013). This is especially so as more wood is needed to produce a small quantity of charcoal with a negative consequence being the depletion of the forest cover, with a significant breakdown in its environmental services. This view is supported by Njenga (2013) and Bailis \& Kammen (2005) who hold that charcoal carbonization process involves large portions of the wood being lost in kilns with only 10\% efficiency (Ackah, 2015; Mugo \& Gathui, 2010). The critical effect of this technique of charcoal production as held by (Penniseet al., 2001) is carbon emissions and forest cover depletion. Mwampamba (2007) agrees with this as he holds that poor kiln efficiencies and low replenishment of harvested forest would completely deplete public forest in Tanzania by 2028. In the long term, his study findings indicate that about 2.28 million hectares of forest will be needed to satisfy charcoal demand in Tanzania by 2030 . This is almost similar to the projections of Iiyama et al. (2014) which stand at 4.4 million hectares of forest to be harvested to meet charcoal demand in Kenya by 2050.

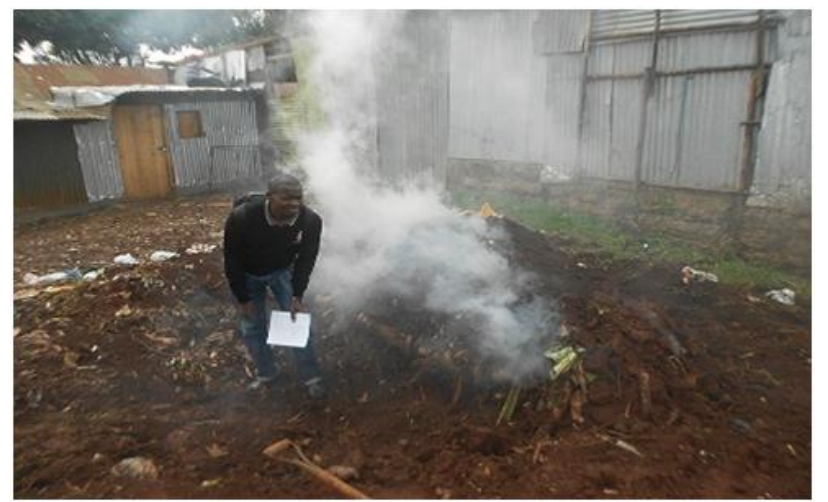

Figure 1: Traditional kiln technique of charcoal production in one of the Nairobi slums

Source: Author's Field Work, 2016.

\subsection{Cooking Stoves used and Cooking Positions Adopted by Charcoal Users}

Figure 2 and Table 3 below present the responses on the type of stove used [Metal stove or the Kenya Ceramic Jiko $(\mathrm{KCJ})]$ and the preferred cooking areas (indoors or outdoors) among the households in Nairobi. 


\section{International Journal of Science and Research (IJSR) \\ ISSN (Online): 2319-7064}

Index Copernicus Value (2013): 6.14 | Impact Factor (2015): 6.391

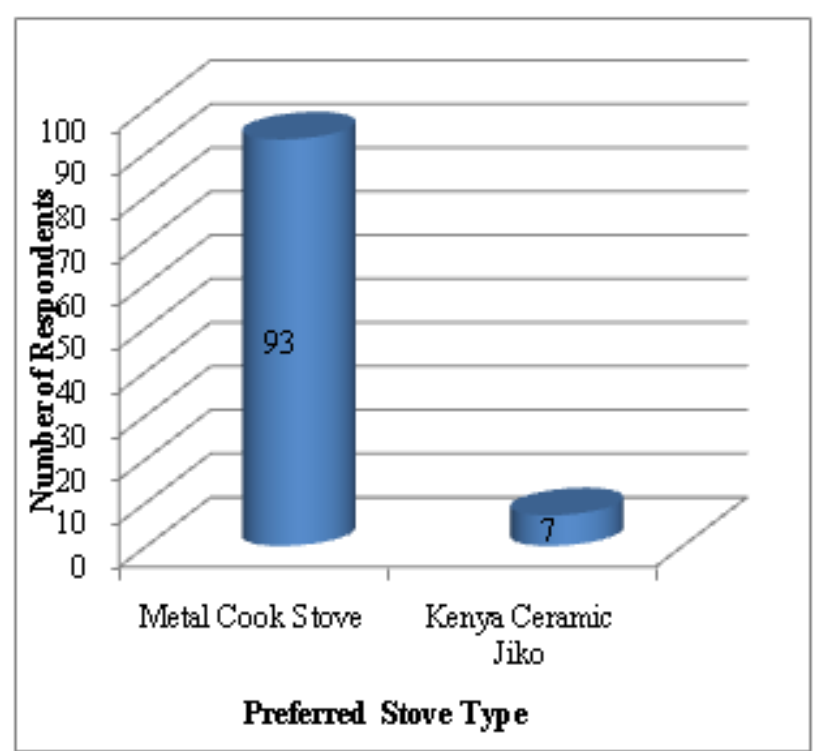

Figure 2: Respondents' Preference for Cook Stoves

The results show that $(93 \% ; \mathrm{N}=100)$ of the respondents preferred metal stoves while only seven percent preferred the Kenya Ceramic Jiko. The reasons for this is perhaps because most of the respondents sampled were either midlevel restaurant operators or were involved in - roasting meat 'nyamachoma' ventures which require heavy duty cooking stoves (metal stoves) to handle their cooking and roasting activities respectively. The other seven percent were households.

Majority $(67 \%)$ of the respondents preferred indoor cooking while $33 \%$ preferred outdoor cooking (Table 3). This again is explained by the fact that meat roasting in Kenya is mostly done in the kitchen indoors and most of the midlevel restaurants located in the city hardly find outdoor space for their cooking activities. Another reason is that these users may not be aware of the effects of their choices on both their health and the environment. Figure 3 presents a photo of some cooking conditions identified during the data collection exercise.

Table 3: Preferred Cooking Environment by Respondents

\begin{tabular}{|c|c|}
\hline Preferred Cooking Environment & Percentage (\%) \\
\hline Indoors & 67 \\
\hline Outdoors & 33 \\
\hline
\end{tabular}

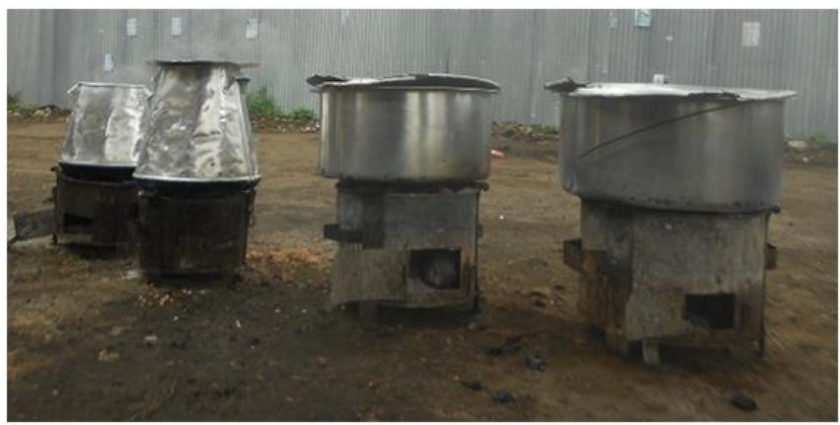

Figure 3: Outdoor Cooking Conditions with Metal Stoves Source: Author's Field Work, 2016

The effect of this finding is like a double-edged sword on the environment and on the health of the users. Outdoor and indoor cooking and heating with charcoal is responsible for air pollution which can be harmful to the health of residents, passersby, restaurant workers and customers (Kim \& Lee, 2012). This view merges well with that of Babcock (2006) who holds that unhealthy indoor air quality remains a serious problem to about $90 \%$ of households who used unprocessed solid fuels for their cooking and heating in developing countries. This aspect is responsible for about four to five percent of the total deaths from lung cancer, asthma, acute respiration infections and other chronic obstructive pulmonary diseases (Smith \& Mehta, 2003). Also, the use of metal cook stoves means large quantity of charcoal which of course leads to deforestation (Kuhnhenn, 2003), with a negative consequence on climate change. This view is in line with those of Bailis \& Kammen (2003) and Kammen (2011), who hold that there is enough evidence that burning biomass inefficiently constitutes a major contributor to climate change.

\subsection{Respondents awareness on the effects of charcoal production and use on the environment}

Figure 4 and Tables 5 and 6 below present the level of awareness of the population in the study area on the effects of charcoal production and use on the environment. Of the 100 charcoal traders and users sampled (Figure 4), 56\% of them (13 charcoal traders and 43 charcoal users) were not aware of the effect of charcoal production and use on the environment, while $44 \%$ said they were aware. Out of these proportions that were aware, 44 were charcoal traders while 37 were charcoal users. Further probing of the $44 \%$ (Table 4) on effects of charcoal producution and use on the environment, with respect to carbon dioxide emission, food supply, water supply, biodiversity loss and informal and formal jobs, majority of them were aware that charcoal production and use increases the carbon dioxide emissions into the atmosphere. However, few people were unaware of how forest cover depletion as a result of charcoal production and use could reduce quality and quantity of food supply (41\%), and reduce water supply (45.5\%). Only $4.5 \%$ and $2.0 \%$ of the respondents respectively were aware of how forest cover depletion enhances biodiversity loss and limits the number of informal and formal jobs 


\section{International Journal of Science and Research (IJSR) \\ ISSN (Online): 2319-7064}

Index Copernicus Value (2013): 6.14 | Impact Factor (2015): 6.391

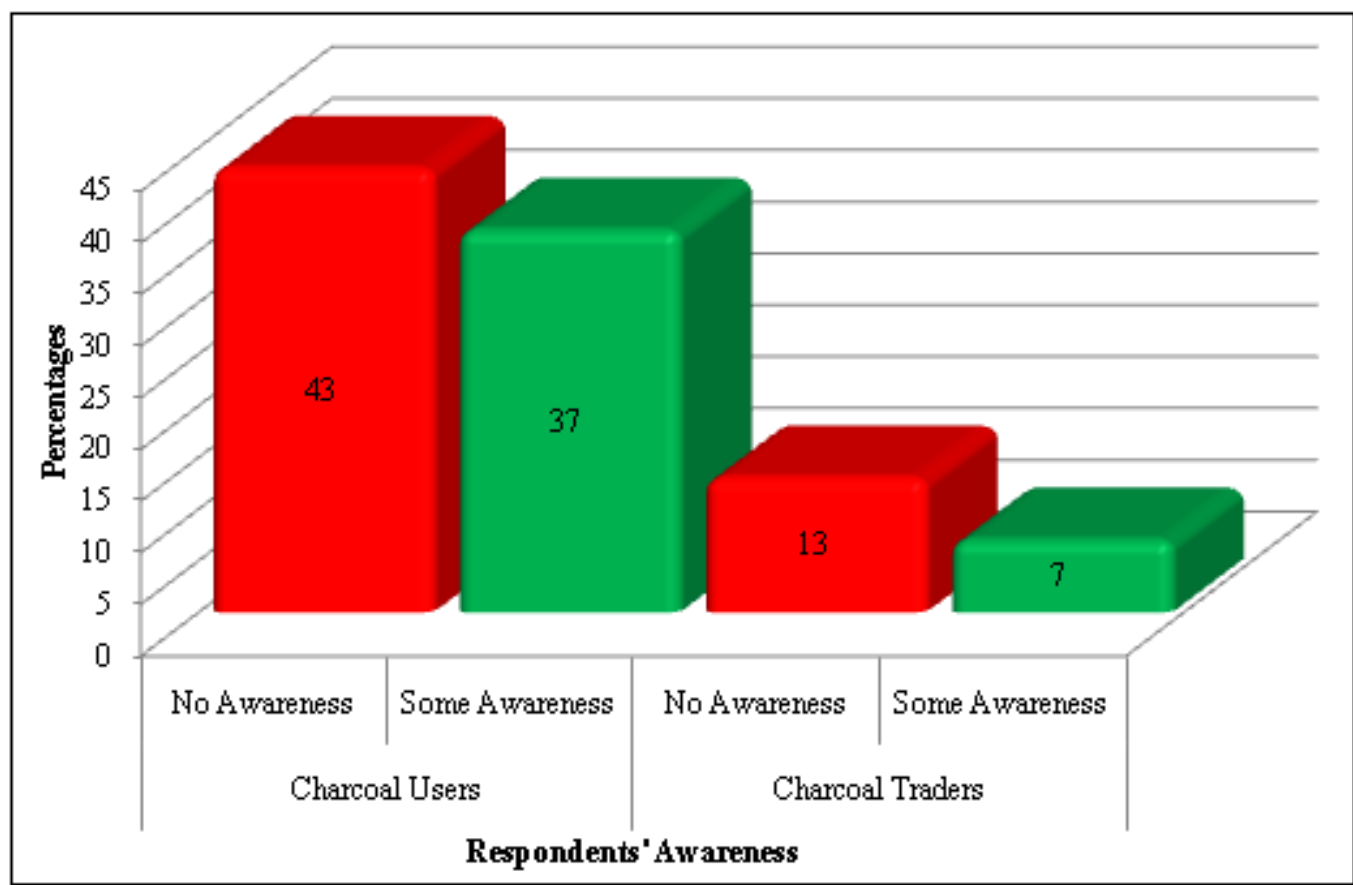

Figure 4: Respondents' Awareness on Effects of Charcoal Production and Use on environment

Table 4: Level of Respondents' Awareness on Effects of Charcoal Production and Use to the Environment

\begin{tabular}{|c|c|c|}
\hline Effects of charcoal production and use: & $\begin{array}{c}\text { Awareness } \\
(\%)\end{array}$ & $\begin{array}{c}\text { Not Aware } \\
(\%)\end{array}$ \\
\hline $\begin{array}{c}\text { Increases Carbon dioxide emissions into } \\
\text { the atmosphere }\end{array}$ & 100 & 0 \\
\hline $\begin{array}{c}\text { Reduces quality and quantity of food } \\
\text { supply }\end{array}$ & 41 & 59 \\
\hline $\begin{array}{c}\text { Reduces water supply (Rainfall, rivers, } \\
\text { steeams, etc) }\end{array}$ & 45.5 & 54.5 \\
\hline Enhances biodiversity loss & 4.5 & 95.5 \\
\hline $\begin{array}{c}\text { Limits the number of informal and } \\
\text { formal jobs }\end{array}$ & 2 & 98 \\
\hline \multicolumn{2}{|c|}{} & \\
\hline
\end{tabular}

Table 5 presents a summary of regression analysis to show the level awareness of charcoal users on the effects of charcoal consumption on forest cover depletion and the environment.

Table 5: Summary linear regression analysis of level of awareness on effects of charcoal on the environment

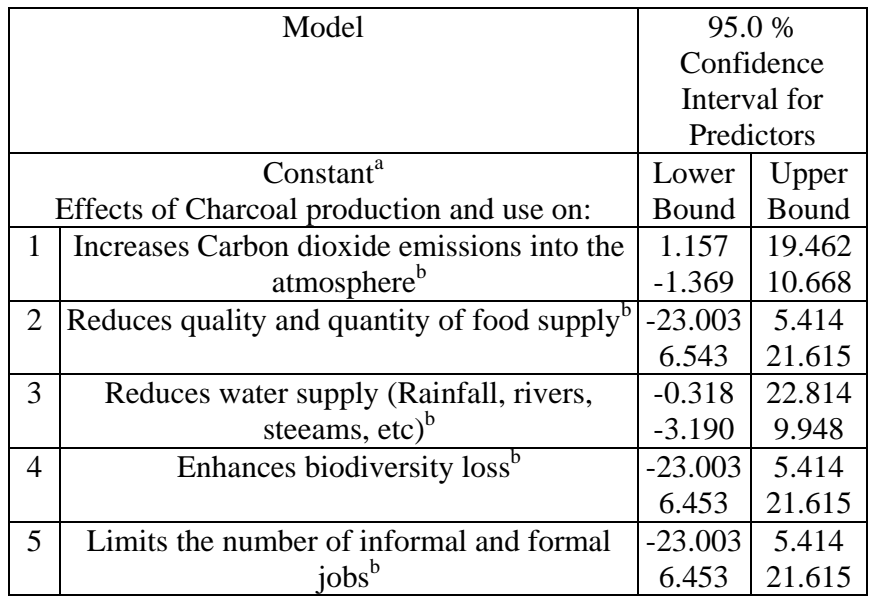

a. Dependent variable (Environmental degradation)

b. All requested Variables entered
At a $95.0 \%$ confidence interval, there was significant low level awareness of charcoal users on the effects of charcoal production and use in enhancing a healthy and sustainable environment in Kenya. Going by the above findings, it could be observed that $56 \%$ of the respondents were not aware of the effect of charcoal production and use on the environment and the green economy. These tie squarely with the findings of Pawar \& Rothkar (2015) who found that most of the charcoal users and producers were not aware of the effects of their actions on the environment and on their wellbeing. However, this finding is different from the findings of Gumbo et al. (2013) in a charcoal scoping study carried out in Zambia, where it was reported that most people were getting to be aware of the negative effects of charcoal production to the environment and forest in particular. During the Key Informants Interview (KII), it emerged that a good number of the population were aware of the environmental effects of charcoal production and use, but they cannot do much since they consider charcoal as the most affordable source of household energy. This was also exacerbated by the cost of acquiring different energy sources, where charcoal becomes a cheaper option. This sentiment supports the reports of Njenga et al. (2013), where charcoal was on high demand and use as a result of energy costs at low income households. Jeremiah et al. (2014) also reported attitude, awareness and social status to be important in decisions on forest management, and hold that if the population is not well informed, conservation efforts are in a challenge.

\section{Conclusion and Recommendations}

The study revealed that charcoal production and use constitute a serious burden to the environment in Kenya where the charcoal is produced largely by the traditional kiln techniques. The heating and cooking is done using metal stoves and the level of awareness of the population on the environmental effects of charcoal production and use is relatively low. Consequently it is important that proper

\section{Volume 5 Issue 6, June 2016} www.ijsr.net 


\section{International Journal of Science and Research (IJSR) \\ ISSN (Online): 2319-7064}

Index Copernicus Value (2013): 6.14 | Impact Factor (2015): 6.391

sensitization of the population on the negative environmental effects of charcoal production is carried on regular basis until charcoal consumption levels decline. This would be steps towards achieving green economy in Kenya and abate the current forest degradation. The population should also be educated on the need to adopt other cleaner and cheaper energy sources like LPG and electricity for their cooking and heating needs. In-depth research on the health effects on charcoal producers and users as a result of widespread traditional charcoal practices is important. However, policies to make these sources cheaper and affordable are needed. This will go a long way to reduce the demand for charcoal and as a result safe the current forest cover in the country. This will lead to mitigation measures at local, national and global levels that occur as a result of forest depletion. The environment and particularly the forest is a major aspect in the drive towards sustainable development and therefore adopting policy framework that will protect the forest from uncontrolled charcoal production is imperative.

\section{References}

[1] Ackah, I. (2015). Empirical relationship between charcoal production and the social cost of carbon emissions. Munich Personal RePEc Archive. Available at http://mpra.ub.uni-muenchen.de/62181/MPRAPaper No. 62181, posted 16. February 2015 15:46 UTC (accessed on 23 February 2015)

[2] Atteridge, A. (2013). Transforming household energy practices to reduce climate risks: Charcoal use in Lusaka, Zambia. Boiling Point. Issue 61-2013.

[3] Babcock, M. (2006).The Effects of Traditional Cooking Technologies and Small Control Interventions on Indoor Air Quality in Cayo Paloma, Panama. Thesis Submitted to Michigan Technological University, USA.

[4] Bailis, R., Ezzati, M., \& Kammen, D. M. (2005).Mortality and Greenhouse Gas Impacts of Biomass and Petroleum Energy Futures in Africa. Science 308, 98 (2005). Retrieved from www.sciencemag.org. Accessed on 14/09/2015.

[5] Bailis, R., Ezzati, M., \& Kammen, D. M. 2003."Greenhouse Gas Emissions from Cooking Technologies in Kenya."Environmental Science \& Technology37(10): 2051-59.

[6] Bekele, M., \& Girmay, Z. (2014). Reading Through the Charcoal Industry in Ethiopia: Production, Marketing, Consumption and Impact. Forum for Social Studies.

[7] Chidumayo, E. N., \& Gumbo, D. J. (2013). The environmental impacts of charcoal production in tropical ecosystems of the world: A synthesis. Energy for Sustainable Development. Vol. 17 (2013) 86-94.

[8] FAOSTATS. (2016). Statistics on Wood Charcoal Production in Kenya. Retrieved from: http://faostat.fao.org/site/626/DesktopDefault.aspx?Pag eID=626\#ancor Accessed: 10/06/2016

[9] Gall, M. D., Borg, W. R., \& Gall, J. P. (2003). Educational research: An introduction. (7th Edition). White Plains, New York: Longman

[10] Gichuho, C. M., Mburu, N. S., \& Wambui, W. F. (2013). Land Cover Change and Deforestation in Gazetted Maji Mazuri Forest, Kenya. International
Journal of Science and Research Vol. 2 Issue 4, April 2013.

[11] Ghilardi, A., \& Steierer, F. (2011). Charcoal production and use: world country statistics and global trends. Paper presented at Symposium: The role of charcoal in climate change and poverty alleviation initiatives, $15^{\text {th }}$ June 2011, Arusha - Zambia.

[12] Gumbo, D. J., Moombe, K. B., Kandulu, M. M., Kabwe, G., Ojanen, M., Ndhlovu, E., \& Sunderland, T.C.H. (2013). Dynamics of the charcoal and indigenous timber trade in Zambia: A scoping study in Eastern, Northern and Northwestern provinces. Occasional Paper 86. CIFOR, Bogor, Indonesia

[13] liyama, M., Neufeldt, H., Dobie, P., Mjenga, M., Ndegwa, G., \& Jamnadass, R. (2014). The potential of agroforestry in the provision of sustainable woodfuel in sub-Saharan Africa. Current Opinion in Environmental Sustainability, 2014, 6:138-147.

[14] Jagger, P. (2014). Confusion vs. clarity: Property rights and forest use in Uganda. Forest Policy and Economics, $45,32-41$.

[15] Jeremiah, R. J., Mbwambo, J. S., \& Dos Santos, A. S. (2014). Attitudes of local communities towards REDD+ Initiatives in Tanzania. A case of selected communities in Kilwa district. International Journal of Physical and Social Sciences, 4 (4), 255.

[16] Johnson, E. (2009). Charcoal versus LPG grilling: A carbon-footprint comparison. Environmental Impact Assessment Review, 29(6), 370-378.

[17] Kammen, D. M. (2011).Household Cookstoves, Environment, Health, and Climate Change: A New Look at an Old Problem. The Environment Department (Climate Change). The World Bank.

[18] Kammen, D. M., \& Lew, D. J. (2005). Review of technologies for the production and use of charcoal. Renewable and Appropriate Energy Laboratory Report, 1.

[19] Kenya Forest Service.(2013). Analysis of the Charcoal Value Chain in Kenya. August 26, 2013. Retrieved from:

http://www.kenyaforestservice.org/documents/redd/Cha rcoal\%20Value\%20Chain\%20Analysis.pdfAccessed 09/09/2015.

[20] Kenya National Bureau of Statistics, (2013).Statistical Abstract, 2013.KNBS, Nairobi, Kenya.

[21] Kim, H., \& Lee, S. (2012). Charcoal Grill Restaurants Deteriorate Outdoor Air Quality by Emitting Volatile Organic Compounds. Pol. J. Environ. Stud. Vol. 21, No. 6 (2012), 1667-1673

[22] Kituyi, E. (2004). Towards sustainable production and use of charcoal in Kenya: exploring the potential in life cycle management approach. Journal of Cleaner Production, 12(8), 1047-1057.

[23] Kuhnhenn, K. (2003). Environmental and socioeconomic Impact of improved Stoves -The Case of the Tsotso Stove in Northern Namibia. Thesis submitted to Lund University Sweden.

[24] Lurimuah, S. (2011).The economic and environmental effects of commercial charcoal production in the Upper West Region of Ghana. Master Thesis submitted to the School of Graduate Studies, Kwame Nkrumah University of Science and Technology, Kumasi Ghana. 
[25] Mohammed, J., Tetteh, I., \& Mills, M. (2013). Fuelwood to Charcoal Production in the New Juaben Municipality of the Eastern Region of Ghana Challenges and Opportunities in Seeking Livelihood. Researchers World, 4(4), 51.

[26] Mugo, F., \& Gathui, T. (2010) Biomass energy use in Kenya. A background paper prepared for the International Institute for Environment and Development (IIED) for an international ESPA workshop on biomass energy, 19-21 October 2010, Parliament House Hotel, Edinburgh. Practical Action, Nairobi, Kenya.

[27] Mutimba, S., \& Barasa, M. (2005). National charcoal survey: Summary report. Exploring the potential for a sustainable charcoal industry in Kenya. Nairobi: Energy for Sustainable Development Africa (ESDA).

[28] Mwampamba, T. H. (2007). Has the fuelwood crisis returned? Urban charcoal consumption in Tanzania and its implications to the present and future forest availability. Energy Policy 35 (2007) 4221-4234

[29] Neuman, W. L. (2000). Social Research Methods: Qualitative and Quantitative Approaches. Boston: Allyn $\&$ Bacon.

[30] Njenga,M., Karanja, N., Munster, C., Iiyama, M., Neufeldt, H., Kithinji, J., \& Jamnadass, R. (2013). Charcoal production and strategies to enhance its sustainability in Kenya. Development in Practice, 23:3, 359-371

[31]Njenga, M. (2013). Evaluating Fuel Briquette Technologies and their Implications on Greenhouse Gases and Livelihoods in Kenya. Ph.D. Thesis Submitted to the Faculty of Agriculture, University of Nairobi.

[32] Njenga, M., Yonemitsu, A., Karanjaa, N., Iiyama, M., Kithinji, J., Dubbeling, M., ...\& Jamnadass, R. R. (2013). Implications of Charcoal Briquette Produced by Local Communities on Livelihoods and Environment in Nairobi Kenya. International Journal of Renewable Energy Development, 2(1), 19.

[33] Pawar, K. V., \& Rothkar, R. V. (2015).Forest Conservation and Environmental Awareness. Procedia Earth and Planetary Science 11 (2015) 212 - 215.

[34] Pennise, D. M., Smith, K. R., Kithinji, J. P., Rezende, M. E., Raad, T. J., Zhang, J., \& Fan, C. (2001). Emissions of greenhouse gases and other airborne pollutants from charcoal making in Kenya and Brazil. Journal of Geophysical Research: Atmospheres (19842012), 106(D20), 24143-24155.

[35] Smith, K. R., \& Mehta, S. (2003). The burden of disease from indoor air pollution in developing countries: comparison of estimates. International Journal of Hygiene and Environmental Health. 206, 279-289.

[36] Tesot, A. K. (2012). Environmental Implications of the Charcoal Business in Narok-South Sub-County, Narok County. Master Thesis presented to Kenyatta University.

[37] Yin, R. K. (2003). Case Study Research: Design and Methods, Sage Publications.

Volume 5 Issue 6, June 2016 www.ijsr.net 